\title{
Chorikiova obrana herců
}

\section{Eliška Poláčková}

Pavlína Š́pová. Apologia mimorum od Chorikia z Gazy. Obrana herců ve jménu Dionýsa. Praha: Karolinum, 2015. $104 \mathrm{~s}$.

Zásluhou Pavlíny Šípové, grécistky a teatroložky, která působí na Ústavu řeckých a latinských studií Filozofické fakulty Univerzity Karlovy, se českému odbornému publiku konečně dostává do rukou poslední z dosud nepřeložených antických teoretických spisů sepsaných na obranu divadla, tzv. apologií. Spolu s Lukianovým pojednáním $O$ tanci ze 2. stol. po Kr. a Libaniovou řečí č. 64, známou pod názvem Aristeidovi o tanečnicich (4. stol. po Kr.), je Apologia mimorum Chorikia z Gazy důležitým zdrojem poučení o divadelních žánrech pěstovaných v pozdní antice na území tehdejší římské říše. Na rozdíl od obou předchůdců, kteří se ve svých pojednáních zabývají především tancem a žánrem jemu příbuzným, pantomimem, věnuje Chorikios svou apologii výhradně mimu, nejvytrvalejšímu ze všech druhů antických divadelních produkcí, o němž však zároveň víme poměrně málo, nebot' se jednalo o žánr částečně improvizovaný, a navíc do značné míry stigmatizovaný.

Autorka v kapitolách, které samotnému překladu předcházejí, předkládá dostupné informace o mimu i o Chorikiově pojednání a o jeho autorovi, což zájemci o antické divadlo jistě ocení, protože dosud byla $\mathrm{v}$ češtině tomto směru $\mathrm{k}$ dispozici pouze základní fakta (viz publikace Evy Stehlíkové, Řecké divadlo klasické doby, 1991; Řimské divadlo, 1993; Divadlo za časů Nerona a Seneky, 2005 a Antické divadlo, 2005). V kapi- tole o vývoji mimu (23-32) se tak čtenář dozví, že tento divadelní žánr pochází zřejmě z Orientu a do Evropy proniknul ve 4. století. př. Kr. Ze Sicílie se rozšíríil na Apeninský poloostrov a do pevninského Řecka a stal se nejdéle existujícím antickým divadelním žánrem vůbec: jeho stopy mizí až po roce 680 , kdy byla mimická a pantomimická představení rozhodnutím Trullánské synody postavena mimo zákon (22). Autorka se podrobně zabývá dochovanými, převážně literarizovanými scénáři mimu a zdůrazňuje skutečnost, že mimos měl evidentně vliv i na autory, kteří se primárně věnovali jinému druhu literatury, např. na básníka Theokrita, jehož idylly č. 2, 14 a 15 bývají označovány za mimy z městského prostředí. Stranou nezůstávají ani inscenační aspekty: čtenář se dozví, že herci mimu pocházeli z nejnižších vrstev společnosti (jednalo se o otroky nebo propuštěné otroky), bylo na ně pohlíženo stejně jako na prostituty a v mimu jako v jediném antickém divadelním žánru mohly vystupovat také ženy - byly ovšem rovněž považovány za prostitutky svého druhu. Otázka obscénnosti mimu je ostatně jedna $\mathrm{z}$ těch, kterými se Chorikios ve svém pojednání zabývá především, a k vyvrácení názoru, že mimos je žánr necudný, směřuje velkou část svého argumentačního úsilí. Jak ovšem autorka poznamenává v úvodu, autor se snaží obhájit neobhajitelné, nebot skutečnost, že mimos obsahoval zápletky 
týkající se nevěry a prostituce a jeho inscenace obnášela např. zpěv eroticky laděných písní, je prostě fakt (10, 40, 41 ad.). $\mathrm{Z}$ dalších inscenačních prvků jsou zmíněny například příležitosti, při kterých byl mimos provozován, či skutečnost, že se jednalo o jediný žánr, ve kterém herci nenosili masky. Samostatná kapitola (33-36) je pak věnována divadelním budovám, jejich využití v pozdní antice a dalším typům prostorů, ve kterých se mohla odehrávat jak představení mimu, tak i další veřejné podívané (napřr. závody vozatajů nebo hony na divoké šelmy). V těchto pasážích by však čtenář ocenil, kdyby bylo jednoznačněji řečeno, zda se všechny uvedené informace týkají pouze byzantského kulturního okruhu, nebo zda se zde čerpá také z autorů, kteří popisují spíše situaci v západní části říše (problém s dobovými prameny je ovšem ten, že právě tuto otázku často nelze uspokojivě zodpovědět; přesto by snad bylo možné na sporné momenty alespoň poukázat).

$\mathrm{V}$ úvodní kapitole autorka rovněž krátce pojednává důležitou otázku povahy divadla provozovaného $\mathrm{v}$ Byzanci a jeho př́ípadné kontinuity $\mathrm{s}$ divadelními žánry řeckého, helénistického a římského období. Zdůrazňuje základní problém, kterým je nejednoznačnost starořecké i latinské divadelní terminologie: je obtížné určit, co přesně má ten který autor na mysli, když píše např. o theatronu (podle kontextu lze přeložit jako divadelní budova, ale také amfiteátr, hipodrom, zábavní umění, představení, drama, vyprávění, scéna, veřejná posluchárna, a konečně i duše, viditelný svět atd.; 14) nebo o mimu, protože tento pojem v pozdní antice kromě konkrétního žánru označoval také divadelní umění jako celek. Teatrolog ovšem v diskuzi poněkud postrádá autorčin názor, kde podle ní kon- čí hranice divadla a začíná ono „ne-divadlo“, tedy, dejme tomu, teatralizované podívané či obecně (kulturní) performance. Tato otázka se přímo nabízí, když autorka hovoří o dramatických prvcích v hymnech a kázáních (14) nebo o pantomimických parodiích předváděných na církevní půdě (20), avšak nevyjádří se explicitně k otázce, zda tyto kulturní projevy chápe jakou součást divadelního umění v širším slova smyslu, či nikoli.

Samotnému textu Chorikiovy apologie se rovněž v knize dostává povšechného komentáře (kapitola „Titul a charakter řeči“, 44-48), stejně jako osobě jejího autora, rétora z palestinské Gazy, který byl učitelem na zdejší významné řečnické škole. Apologie je nejspíše řečnickým cvičením, jež má formu soudní obhajovací řeči, avšak z dostupných informací není možné určit, zda byla přednesena při reálném soudním přelíčení, nebo jen pro potěchu posluchačů (44). Text obhajoby je v knize přetištěn jednak v originále, jednak v českém znění, které je po italské a novořecké verzi teprve třetím úplným překladem Apologie do moderního jazyka (47).

Jakkoli se jedná o publikaci nadmíru cennou, nelze se v závěru ubránit drobné kritice, či spíše povzdechu nad její formální nedotažeností. Následující výtky jsou směřovány především nakladatelství Karolinum, které knihu připravilo k tisku a od něhož by čtenář očekával redakční práci adekvátní hodnotě věcného obsahu knihy (v tiráži je jako redaktorka uvedena Barbora Přerostová). S očekáváním bohužel nekoresponduje zarážející množství typografických, gramatických i stylistických chyb, jež se vyskytují v úvodních kapitolách i v samotném překladu. Z typografických nedostatků jmenujme namátkou chybějící velká písmena (9), závorky (11) a kurzívu (30), 
dále překlepy (46) či případně nesprávné znění latinských citátů (např. sousloví panem et circense[s], 13). Gramatická pochybení se pak týkají zejména nesprávného dělení vět pomocí interpunkčních znamének, aktuálního větného členění a nedodržování valence či pravidel pádové syntaxe. $\mathrm{V}$ neposlední řadě úvodní texty trpí mnoha stylisticky neobratnými formulacemi (např. „tento den byl pak oslavován pod slavným jménem“, 39). Totéž je možno říci i o samotném překladu, který je navíc místy př́iliš závislý na jazyce originálu, např. v nadužívání ukazovacích zájmen a naopak v nedostatečném užívání apelativ (takže ve výsledku někdy není jasné, o kom/čem se mluví; např. 50, 55 ad.). Určité množství chyb se samozřejmě vyskytuje v každé publikaci a bylo by malicherné na to $\mathrm{v}$ recenzi poukazovat. $\mathrm{V}$ prrítomném textu se však nějaké opomenutí vyskytuje téměř na každé stránce; někdy je navíc natolik závažné, že ztěžuje, či zcela znemožňuje pochopení (např. z věty „i scholastik Nikotychos si kdysi rád s mimy zadal a hrával hry od mimografa Filistiona“ [43] není jasné, zda byl řečený Nikotychos hercem, principálem herecké skupiny, nějakým druhem pro- dukčního apod.). Kromě toho se v knize objevuje také několik míst, která jsou obsahově zavádějící: např. z informace, že herci mimu nenosili masky, což jim umožňovalo používat mimiku a zpívat (26), by čtenář mohl nabýt dojmu, že v ostatních žánrech, jež byly maskované, se tudíž zpěv nevyužíval, což ovšem není pravda. Takovýchto nepřesností je nicméně $\mathrm{v}$ textu minimum a pečlivější redakce by je jistě snadno odhalila.

Lze jen litovat, že se knize ze strany odpovědné redaktorky nedostalo více péče, nebot' naznačené skutečnosti poněkud kalí potěšení ze čtení jinak velmi zajímavé a přínosné publikace, která dovoluje nahlédnout jak divadelní život ve východní části římského impéria v období pozdní antiky, tak konkrétní text, mimochodem výrazně performativního charakteru, v němž jeho autor, milovník divadla, živě a nápaditě „obhajuje neobhajitelné“ - divadelní žánr, který vzbuzoval vášně mezi diváky, kteří mimické produkce sledovali s nadšením, i mezi těmi, kdo na ně pohlíželi s odporem a pohrdáním.

DOI: $10.5817 /$ TY2016-1-18 